CLINICAL STUDY

\title{
Vitamin D therapy in patients with primary hyperparathyroidism and hypovitaminosis D
}

\author{
J R Tucci ${ }^{1,2,3}$ \\ ${ }^{1}$ Division of Endocrinology, Department of Medicine, Roger Williams Medical Center, 825 Chalkstone Avenue, Providence, Rhode Island 02908-4728, \\ USA, ${ }^{2}$ Boston University School of Medicine, Boston, Massachusetts, USA, and ${ }^{3}$ The Warren Alpert Medical School of Brown University, Providence, \\ Rhode Island, USA \\ (Correspondence should be addressed to J R Tucci; Email: umgtucci@yahoo.com)
}

\begin{abstract}
Objective: To determine whether vitamin D repletion of patients with primary hyperparathyroidism (PHPT) and vitamin D deficiency or insufficiency (hypovitaminosis D) has deleterious clinical and/or biochemical effects.

Design: Prospective audit of the effect of vitamin D repletion on biochemical data in 56 patients with PHPT. Patients were treated with 50000 units of vitamin $\mathrm{D}_{2}$ weekly for 8 weeks with biochemical measurements at 5 and 10 weeks, and subsequently after 12 weeks on 800 units of vitamin $\mathrm{D}_{3}$ daily, and in those with hypovitaminosis $\mathrm{D}$ after 12 weeks of up to 100000 units of vitamin $\mathrm{D}_{2}$ monthly.

Methods: Serum calcium, albumin, phosphorus, 25-OHD, intact parathyroid hormone (PTH) and urine calcium/creatinine $(\mathrm{Ca} / \mathrm{Cr})$ ratios were measured before and during vitamin $\mathrm{D}$ therapy.

Results: Patients treated with 50000 units of vitamin $\mathrm{D}_{2}$ weekly for 8 weeks resulted in a significant increase in serum 25-OHD levels from 36.4 to $89.4 \mathrm{nmol} / \mathrm{l}$ at 5 weeks $(P<0.0001)$ and $88.6 \mathrm{nmol} / \mathrm{l}$ at 10 weeks $(P<0.0001)$. There were no significant changes in serum calcium. At 10 weeks, there was a non-significant decrease in serum PTH and in urine $\mathrm{Ca} / \mathrm{Cr}$ ratios. None of the patients developed any calcium-related adverse events. Subsequently, patients with subnormal 25-OHD levels on 800 units of vitamin D daily were treated for the next 12 weeks with up to 100000 units of vitamin $\mathrm{D}_{2}$ monthly with normalization of serum 25-OHD in all but 4 patients.

Conclusion: These data fail to demonstrate any adverse effects of vitamin D repletion in PHPT.
\end{abstract}

European Journal of Endocrinology 161 189-193

\section{Introduction}

Hypovitaminosis D is an inclusive term for vitamin D deficiency and insufficiency. It is a problem in all age groups in the general population nationally and worldwide $(1,2)$ and is seen frequently in those with a number of clinical disorders including primary hyperparathyroidism (PHPT) $(3,4)$. There is no universal agreement in defining vitamin D insufficiency, with some authors indicating a cut-off point of $\leq 20 \mathrm{ng} / \mathrm{ml}(50 \mathrm{nmol} / \mathrm{l})$ for serum $25-\mathrm{OHD}(2,5,6)$ while for many others it is $\leq 30 \mathrm{ng} / \mathrm{ml}(75 \mathrm{nmol} / \mathrm{l})$ (1, 7-11). In the present study of vitamin D therapy in patients with PHPT, vitamin D insufficiency is defined by a serum level of $21-29 \mathrm{ng} / \mathrm{ml}(52.5-72.5 \mathrm{nmol} / \mathrm{l})$ and vitamin D deficiency by a serum 25-OHD level of $\leq 20 \mathrm{ng} / \mathrm{ml}(\leq 50 \mathrm{nmol} / \mathrm{l})$. In patients with PHPT, subnormal serum 25-OHD levels have been associated with larger parathyroid glands and parathyroid tumours, higher serum parathyroid hormone (PTH), calcium and alkaline phosphatase levels, accelerated bone turnover and a greater likelihood of abnormal bone and fractures $(3,4,12,13)$. Whereas vitamin D repletion is routinely recommended for patients with hypovitaminosis $\mathrm{D}$, there has been reluctance to restore serum 25-OHD levels to normal in PHPT due to concerns of potentially greater hypercalcaemia and hypercalciuria $(3,14)$. In 1997, Zahrani et al. indicated that until more data are available, patients with PHPT should moderate their intake of dietary calcium and avoid any calcium or vitamin D supplements (15). Recently, Grey et al. reported preliminary observations in 21 patients with PHPT treated with vitamin D (16). Except for two patients who exhibited greater calcium excretion, vitamin D therapy was not associated with adverse clinical or biochemical effects. This report represents a prospective audit of clinical, biochemical and hormonal data in 56 patients with PHPT and hypovitaminosis $\mathrm{D}$ before and during treatment with vitamin D from the years 2002-2008. 


\section{Subjects and methods}

\section{Patients}

Patients with PHPT include 37 females and 19 males. Serum calcium levels ranged from 2.63 to $3 \mathrm{mmol} / \mathrm{l}$ and serum 25-OHD from 17.5 to $60 \mathrm{nmol} / \mathrm{l}$. All 56 patients did meet criteria for diagnosis of PHPT. Most patients were asymptomatic, but there were 14 patients who did meet criteria for surgery. Subsequent to vitamin D therapy, those 14 patients with preexisting indications for surgery unrelated to vitamin D therapy did undergo successful surgical treatment of their hyperparathyroidism.

\section{Vitamin D replacement}

Patients were treated with 50000 units $(1.25 \mathrm{mg})$ of ergocalciferol each week for 8 weeks and, subsequently, on the basis of serum 25-OHD levels, doses of vitamin D varied from 800 units daily to as much as 100000 units monthly in an effort to maintain serum 25-OHD levels at $\geq 75 \mathrm{nmol} / \mathrm{l}$.

\section{Hormonal and biochemical measurements}

At baseline, serum calcium, albumin, phosphorus, alkaline phosphatase, creatinine, 25-OHD, and intact PTH were measured. In 39 patients, serum 1,25-OHD levels were also measured. Second-voided morning urine specimens were collected for measurement of creatinine, $N$-telopeptide (NTx) and calcium. At 5 and 10 weeks during and just following the 8 weeks of vitamin D therapy, serum calcium, phosphorus and 25-OHD levels were measured. Serum intact PTH and urine NTx, creatinine and calcium were also measured at 10 weeks. Approximately 12 weeks later, while on maintenance therapy with 800 units of vitamin D daily, serum calcium, phosphorus and 25-OHD were measured and those with subnormal serum 25-OHD levels were then treated with 50000 units once or twice monthly. Serum calcium, phosphorus and 25-OHD levels were again measured 12 weeks later at 34 weeks.

Blood chemistries were measured on the ADVIA1650 chemistry analyser, Siemens Healthcare Diagnostics, Medical Solutions, Tarrytown, NY, USA. Serum 25-OHD level was measured by extraction of $D_{2}$ and $D_{3}$ followed by liquid chromatography and tandem mass spectroscopy, Mayo Medical Laboratory, Rochester, MN, USA. Serum intact PTH was measured by chemiluminescence immunoassay, Centaur Analyser, Siemens Healthcare Diagnostics, Medical Solutions. Serum 1,25-OHD was determined by precipitation and extraction followed by RIA using a polyclonal antibody, Diasorin Inc., Stillwater, MN, USA. Urine NTx was measured by competitive immunoassay technique on the Vitros ECi analyser, Ortho-Clinical Diagnostics, Inc., Rochester, NY, USA.

Standard descriptive statistical methods and paired $t$-tests were used to assess the significance of differences of biochemical and hormonal values before and during vitamin D therapy. Differences were considered statistically significant at a $P$ value of $<0.05$ by a two-tailed test. Linear regression analysis was utilised in assessing the relationship of serum calcium and PTH levels to serum 25-OHD levels and of serum 1,25-OHD to serum 25-OHD, PTH and phosphate.

\section{Results}

Biochemical and hormonal data before initiation of therapy with vitamin D in 56 patients with PHPT are presented in Table 1. Serum calcium levels varied from 2.6 to $3 \mathrm{mmol} / \mathrm{l}$ and serum intact PTH from 52 to $416 \mathrm{ng} / \mathrm{l}$. Serum $25-\mathrm{OHD}$ varied from 17.5 to $60 \mathrm{nmol} / \mathrm{l}$ with 51 patients having vitamin D deficiency and five having vitamin D insufficiency. Of the 39 patients who had serum 1,25-OHD measurements at baseline, nine had increased serum 1,25-OHD of $163-223 \mathrm{pmol} / \mathrm{l}$ while one patient had a low level

Table 1 Baseline biochemical and hormonal data in patients with primary hyperparathyroidism and normal range of values.

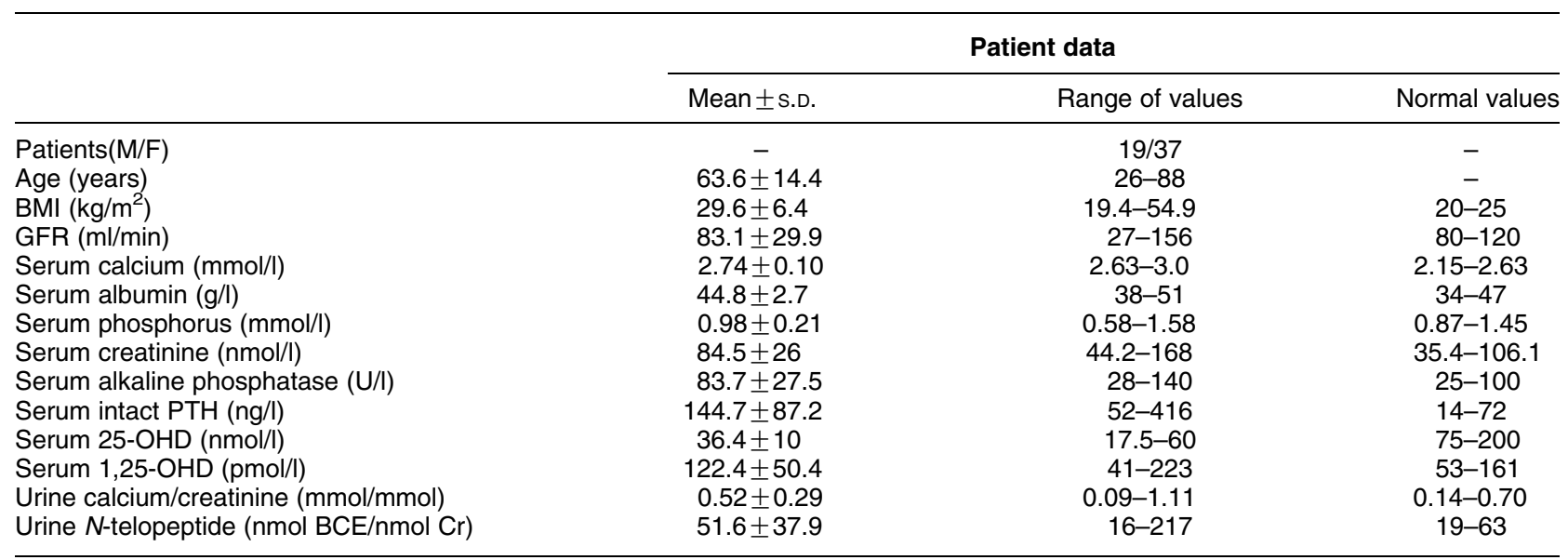


of $41 \mathrm{pmol} / \mathrm{l}$. Regression analysis failed to reveal any relationship between serum 1,25-OHD and 25-OHD levels $(R=0.28, \quad P=0.19)$, serum $25-0 H D$ and calcium levels $(R=0.06, P=0.44)$, serum calcium and PTH levels $(R=0.25, P=0.07)$ or between serum PTH and 1,25-OHD levels $(R=0.28, P<0.08)$. There was an inverse relationship between serum phosphate and 1,25-OHD levels $(R=0.42, P=0.01)$.

During treatment with vitamin $D$, none of the patients developed any calcium-related complaints or adverse events. Following treatment with vitamin D, fourteen patients were subsequently treated surgically because of pre-existing history of calcium urolithiasis, serum calcium levels consistently more than $1 \mathrm{mg} / \mathrm{dl}$ $(0.25 \mathrm{mmol} / \mathrm{l})$ above the upper limit of normal, osteoporosis, MEN syndrome type 1 and in one case for personal reasons. The decision to treat surgically was not due to any adverse effects of vitamin D therapy.

Biochemical and hormonal data, and vitamin D status before and during therapy with vitamin D are presented in Table 2. With vitamin D therapy, there was a significant increase in serum 25-OHD levels rising from $36.4 \pm 10 \mathrm{nmol} / \mathrm{l}$ at baseline to $89.4 \pm 33.3$ and $88.6 \pm 29.7 \mathrm{nmol} / \mathrm{l}$ at 5 and 10 weeks respectively $(P<0.0001)$. At 5 weeks, serum 25-OHD levels varied from 37.5 to $167.5 \mathrm{nmol} / \mathrm{l}$ with 10 patients having vitamin D insufficiency levels of $52.5-72.5 \mathrm{nmol} / \mathrm{l}$ and three patients with vitamin $\mathrm{D}$ deficiency levels of 37.5-45 nmol/l. At 10 weeks, serum 25-OHD levels varied from 42.5 to $162.5 \mathrm{nmol} / \mathrm{l}$ with vitamin D insufficiency in 17 patients with levels of 52.5-72.5 nmol/l and vitamin D deficiency in five patients with levels of $42.5-50 \mathrm{nmol} / \mathrm{l}$. For the following 12 weeks with a maintenance dose of 800 units of vitamin D daily, there was a significant decrease in serum 25-OHD to $65.7 \mathrm{nmol} / \mathrm{l}$ $(P<0.0001)$. There were 12 patients with vitamin $\mathrm{D}$ insufficiency $52.5-72.5 \mathrm{nmol} / \mathrm{l}$ and 10 with vitamin D deficiency $27.5-50 \mathrm{nmol} / \mathrm{l}$. In these patients with continuing hypovitaminosis D, 50 000-100 000 units of vitamin D monthly normalised serum 25-OHD levels in all but four who had levels of $62.5-72.5 \mathrm{nmol} / \mathrm{l}$.

There were no significant changes in serum calcium or phosphorus at 5 or 10 weeks versus baseline levels. At 5 weeks, in one patient, serum calcium rose from 2.93 to $3.08 \mathrm{mmol} / \mathrm{l}$. At 5 weeks, in patients with normal serum 25-OHD levels, serum calcium ranged from 2.6 to $3.08 \mathrm{mmol} / \mathrm{l}$. In those with subnormal 25-OHD levels, serum calcium varied from 2.6 to $2.95 \mathrm{mmol} / \mathrm{l}$. Mean serum calcium levels in these two groups were not significantly different. At 10 weeks, there were two patients in whom serum calcium rose from 2.8 to 3.03 $\mathrm{mmol} / \mathrm{l}$ and 2.83 to $3.05 \mathrm{mmol} / \mathrm{l}$. At 10 weeks, in patients with normal serum 25-OHD levels, serum calcium ranged from 2.6 to $3.03 \mathrm{mmol} / \mathrm{l}$ while in those with subnormal 25-OHD levels, serum calcium varied from 2.6 to $3.05 \mathrm{mmol} / \mathrm{l}$. In these two groups, mean serum calcium levels were not significantly different.

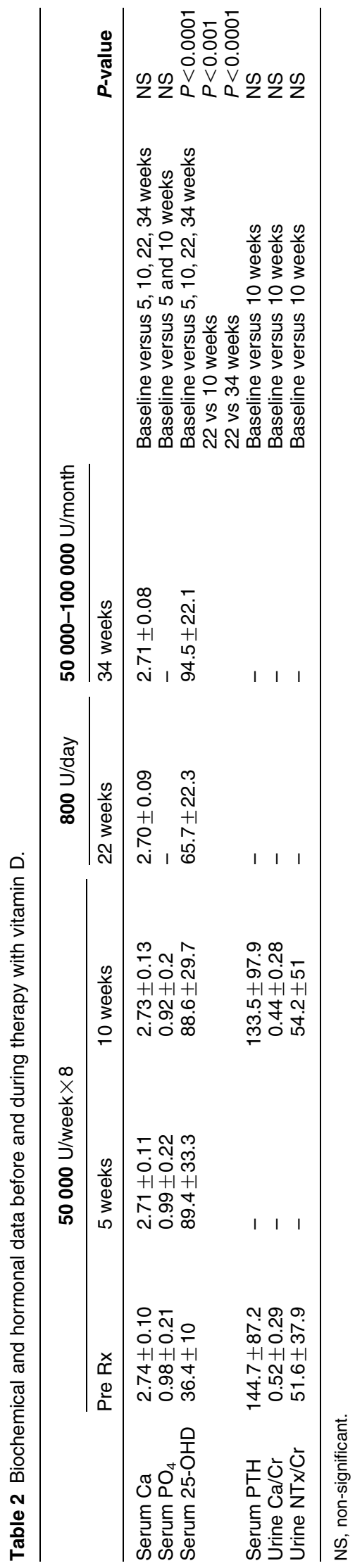

www.eje-online.org 
Regression analysis failed to reveal any relationship between serum calcium and serum 25-OHD levels before and during vitamin D therapy. At 10 weeks, there was a non-significant decrease of $8 \%$ in serum intact PTH from a mean of 145-134 ng/l. Serum 25-OHD and PTH levels were not correlated $(R=0.08, P=0.41)$, but serum calcium and PTH levels were correlated $(R=0.41$, $P=0.002)$. There was also a non-significant decrease in urine calcium creatinine $(\mathrm{Ca} / \mathrm{Cr})$ ratios at 10 weeks compared with baseline. Pre-therapy values ranged from 0.09 to 1.11 and at 10 weeks from 0.14 to 1.08 . There was no significant difference in urine NTx at 10 weeks versus pre-therapy levels.

\section{Discussion}

Hypovitaminosis D is a common clinical finding in the general population and in a variety of clinical disorders including PHPT (1-4). In 1971, Woodhouse et al. reported two patients with PHPT, one with severe osteitis fibrosa cystica, and the other with subperiosteal cortical erosions (17). Treatment with a single injection of 50000 units of vitamin $\mathrm{D}_{3}$ followed by 1500 units daily for up to 16 months in the patient with osteitis fibrosa cystica and 500 units of vitamin D daily in the second patient for 11 months resulted in normalisation of serum alkaline phosphatase levels, remineralisation of bone, and healing of subperiosteal cortical bone erosions. The authors postulated that vitamin D deficiency may occur as a consequence of an increase in PTH secretion. The available data now suggest that in PHPT there is increased catabolism and inactivation of vitamin $\mathrm{D}$ related to increases in 1,25-OHD that are attributable to the hyperparathyroidism (18, 19). Halloran et al. reported that chronic 1,25-OHD administration in rats reduces serum 25-OHD levels by an increase in its clearance and in biliary excretion of degradation metabolites (20). Subsequently, Clements et al. reported a shortened elimination half-time of infused 25-OHD in patients with PHPT with reversion toward normal following parathyroidectomy (18). These results were thought to be consistent with increased hepatic inactivation and biliary excretion of metabolites.

Silverberg et al. found that $53 \%$ of their patients with PHPT had serum 25-OHD levels of $<50 \mathrm{nmol} / \mathrm{l}$ (3). Those patients with the lowest serum 25-OHD levels had the highest serum PTH levels and more pronounced changes in biochemical, densitometric and histomorphometric indices of skeletal metabolism. Carnevale et al. reported serum 25-OHD levels of $\leq 30 \mathrm{nmol} / \mathrm{l}$ in $27 \%$ of their patients with PHPT (21). Rao et al. reported that suboptimal vitamin D nutrition stimulates parathyroid adenoma growth with a significant inverse relationship between serum 25-OHD levels and parathyroid gland weight (4). Their data confirmed earlier reports that parathyroid tumour weight was a significant determinant of disease severity as reflected by serum PTH, calcium and alkaline phosphatase levels. These authors indicated that while limiting intake of vitamin $\mathrm{D}$ and calcium has often been advised in the hope of avoiding a worsening hypercalcaemia, such an approach would lead to increased PTH secretion, higher bone turnover and greater cortical bone loss. They concluded that patients with PHPT need at least as much vitamin D as patients without hyperparathyroidism and possibly more, and that a certain level of calcium intake would be appropriate to prevent greater bone resorption.

An NIH consensus conference relating to the management of asymptomatic PHPT in 2002 delineated guidelines for those patients who should be treated surgically and those who could be followed safely without surgical intervention (22). Any longterm therapy with vitamin $\mathrm{D}$ should pertain only to patients with so-called asymptomatic PHPT in whom there are no clear-cut surgical considerations. However, though vitamin D repletion is an accepted therapy for the general population, in 1999 Silverberg et al. felt that vitamin $\mathrm{D}$ administration in patients with PHPT can be 'difficult if not dangerous because of potential hypercalcaemic and hypercalciuric effects of vitamin D' (3). Accordingly, vitamin D therapy was not recommended for such patients. Kantorovich et al. reported biochemical and hormonal data in three patients with PHPT who were treated with 100000 units of vitamin $\mathrm{D}_{2}$ weekly for 5 weeks (23). Serum calcium levels before and after therapy were 11 and $10.9 \mathrm{mg} / \mathrm{dl}(2.75$ and $2.73 \mathrm{mmol} / \mathrm{l}), 10.5$ and $10.9 \mathrm{mg} / \mathrm{dl}(2.63$ and $2.73 \mathrm{mmol} / \mathrm{l})$, and 10.7 and $10.4 \mathrm{mg} / \mathrm{dl}(2.68$ and $2.6 \mathrm{mmol} / \mathrm{l}$ ) with serum PTH levels falling in two of the three patients. Remineralisation of bone occurred and the subperiosteal cortical bone erosions healed.

Recently, Grey et al. reported biochemical data in 21 patients with mild PHPT with serum calcium levels $\leq 12 \mathrm{mg} / \mathrm{dl}$ ( $\leq 3 \mathrm{mmol} / \mathrm{l})$ and serum 25-OHD levels $<20 \mathrm{ng} / \mathrm{ml}(<50 \mathrm{nmol} / \mathrm{l})$ who were treated with 50000 units of vitamin $\mathrm{D}_{3}$ weekly for 1 month followed by 50000 units monthly for 12 months (16). With therapy, there was no significant change in serum calcium levels, with no serum calcium rising above $12 \mathrm{mg} / \mathrm{dl}$ ( $3 \mathrm{mmol} / \mathrm{l})$. There was a significant decrease in serum intact PTH levels by $24 \%$ at 6 months and by $26 \%$ at 12 months. There was a non-significant decrease in urine NTx. Except for increases to over $400 \mathrm{mg}(10 \mathrm{mmol})$ of calcium in 24-h urine in two patients, mean values were unchanged. These authors concluded that repletion of body stores of vitamin D in patients with mild PHPT and hypovitaminosis D may be safe with no evidence of worsening hypercalcaemia. However, they suggested larger studies to assess safety and efficacy of such therapy.

The data herein reported support the observations of Grey et al. (16) that vitamin D therapy is, indeed, safe in patients who have coexistent mild PHPT with serum calcium levels of up to $3 \mathrm{mmol} / \mathrm{l}$ and hypovitaminosis D. 
None of the patients treated with vitamin D developed any calcium-related symptoms or adverse events. The therapeutic regimens did differ somewhat in that in the study of Grey et al. 50000 units of vitamin $\mathrm{D}_{3}$ were given weekly for 4 weeks followed by 50000 units monthly. In the present study, 50000 units of vitamin $\mathrm{D}_{2}$ were given weekly for 8 weeks followed by 800 units of vitamin $\mathrm{D}_{3}$ for up to 12 weeks. Those patients with subnormal serum 25-OHD levels, were then treated with 50 000-100 000 units of vitamin $\mathrm{D}_{2}$ monthly. Despite significant increases in serum 25-OHD with vitamin D administration, there was no significant increase in serum calcium or urinary $\mathrm{Ca} / \mathrm{Cr}$ ratios. There was a non-significant decrease in serum PTH levels. In 23 patients, monthly doses of up to 100000 units of vitamin $\mathrm{D}$ were necessary to restore or maintain serum $25-\mathrm{OHD}$ levels at $\geq 75 \mathrm{nmol} / \mathrm{l}$. These findings do not support the generally accepted position that therapy with vitamin $\mathrm{D}$ is dangerous in PHPT. When one considers the potential long-term deleterious skeletal effects of untreated hypovitaminosis D, particularly in patients with PHPT $(4,12)$, such a position now seems untenable. Also, the increasing evidence of positive non-skeletal or non-classic effects of vitamin D $(1,24)$ would support optimisation of vitamin D levels in patients with PHPT especially in those in whom a decision has been made for indefinite monitoring rather than definitive surgical therapy. However, demonstration of any positive skeletal or non-skeletal effects would require long-term studies.

\section{Declaration of interest}

There is no conflict of interest that could be perceived as prejudicing the impartiality of the research reported.

\section{Funding}

This research did not receive any specific grant from any funding agency in the public, commercial or not-for-profit sector.

\section{References}

1 Holick MF. Vitamin D deficiency. New England Journal of Medicine $2007357266-281$.

2 Lips P, Duong T, Oleksik A, Black D, Cummings S, Cox D \& Nickelsen T. A global study of vitamin D status and parathyroid function in postmenopausal women with osteoporosis: baseline data from the multiple outcomes of raloxifene evaluation clinical trial. Journal of Clinical Endocrinology and Metabolism 200186 1212-1221.

3 Silverberg SJ, Shane E, Dempster DW \& Bilezekian JP. The effects of vitamin D insufficiency in patients with primary hyperparathyroidism. American Journal of Medicine 1999107 561-567.

4 Rao DS, Honasage M, Divine GW, Phillips ER, Lee MW, Ansari MR, Talpos GB \& Parfitt AM. Effect of vitamin D nutrition on parathyroid adenoma weight: pathogenetic and clinical implications. Journal of Clinical Endocrinology and Metabolism 200085 1054-1058.

5 Vieth R, Ladak Y \& Walfish PG. Age-related changes in the 25-hydroxyvitamin D versus parathyroid hormone relationship suggest a different reason why older adults require more vitamin D. Journal of Clinical Endocrinology and Metabolism 200388 185-191.
6 Hansen KE, Jones AN, Lindstrom MJ, Davis LA, Engelke JA \& Shafer MM. Vitamin D insufficiency: disease or no disease. Journal of Bone and Mineral Research 200823 1052-1060.

7 Holick MF. High prevalence of vitamin D inadequacy and implications for health. Mayo Clinic Proceedings 2006 81 353-357.

8 Bischoff-Ferrari HA, Giovannucci E, Willett WC, Dietrich T \& Dawson-Hughes B. Estimation of optimal serum concentration of 25-hydroxy vitamin D for multiple health outcomes. American Journal of Clinical Nutrition $2006 \mathbf{8 4} 18-28$.

9 Malabanan A, Veronikis IE \& Holick MF. Redefining vitamin D insufficiency. Lancet $1998351805-806$.

10 Thomas KK, Lloyd-Jones DM, Thadhani RI, Shaw AC, Deraska DJ, Kitch BT, Vamvakas FC, Dick IM, Prince RI \& Finkelstein JS. Hypovitaminosis D in medical inpatients. New England Journal of Medicine 1998338 777-783.

11 Dawson-Hughes B, Heaney RP, Holick MF, Lips P, Meunier PJ \& Vieth R. Estimates of optimal vitamin D status. Osteoporosis International 200516 713-716.

12 Rao DS, Agarwal G, Talpos GB, Phillips ER, Bandeira F, Mishra SK \& Mithal A. Role of vitamin D and calcium nutrition in disease expression and parathyroid tumor growth in primary hyperparathyroidism: a global perspective. Journal of Bone and Mineral Research 200217 N75-N80.

13 Nordenstrom E, Westerdahl J, Lindergard B, Lindblom P \& Bergenfelz A. Multifactoral risk profile for bone fractures in primary hyperparathyroidism. World Journal of Surgery 200226 1463-1467.

14 Bilezekian JP. Primary hyperparathyroidism. When to observe and when to operate. Endocrinology and Metabolism Clinics of North America 200029 456-478.

15 Zahrani AA \& Levine MA. Primary hyperparathyroidism. Lancet $19973491233-1238$.

16 Grey A, Lucas J, Horne A, Gamble G, Davidson JS \& Reid IR. Vitamin D repletion in patients with primary hyperparathyroidism and coexistent vitamin D insufficiency. Journal of Clinical Endocrinology and Metabolism $2005902122-2126$.

17 Woodhouse NJY, Doyle FH \& Joplin GF. Vitamin D deficiency and primary hyperparathyroidism. Lancet 19712 283-286.

18 Clements MR, Davies M, Fraser DR, Lumb GA, Barbara-Mawer E \& Adams PH. Metabolic inactivation of vitamin D is enhanced in primary hyperparathyroidism. Clinical Science 198773 659-664.

19 Clements MR, Davies ME, Hayes ME, Hickey CD, Lumb GA, Mawer B \& Adams PH. The role of 1,25-dihydroxyvitamin D in the mechanism of acquired vitamin D deficiency. Clinical Endocrinology 199237 17-27.

20 Halloran BP, Bikle DD, Levens MJ, Castro ME, Globus RK \& Holton E. Chronic 1,25-dihydroxyvitamin D administration in the rat reduces the serum concentration of 25-hydroxyvitamin D by increasing metabolic clearance rate. Journal of Clinical Investigation 198678 622-628.

21 Carnevale V, Manfredi G, Romagnoli E, De Geronimo S, Paglia F, Pepe J, Scillitani A, D'Erasmo E \& Minisola S. Vitamin D status in female patients with primary hyperparathyroidism: does it play a role in skeletal damage? Clinical Endocrinology 200460 81-86.

22 Bilezekian JP, Potts JT Jr \& Fuleihan GE. Summary statement from a workshop on asymptomatic primary hyperparathyroidism: a perspective for the 21 st century. Journal of Bone and Mineral Research 200217 N2-N10.

23 Kantorovich V, Gacad MA, Seeger LL \& Adams JS. Bone mineral density increases with vitamin $D$ repletion in patients with coexistent vitamin D insufficiency and primary hyperparathyroidism. Journal of Clinical Endocrinology and Metabolism 200085 3541-3543.

24 Bouillon R, Bischoff-Ferrari H \& Willet W. Perspective. Vitamin D and health: perspectives from mice and man. Journal of Bone and Mineral Research 200823 974-979.

Received 16 April 2009

Accepted 18 April 2009 